\title{
Perceptions Of Undergraduate Business Students Toward Online Courses In Higher Education Expanded And Revisited: Do Gender, Age, And/Or Past Experiences Make A Difference?
}

John R. Tanner, (E-mail: jrt4671@ @louisiana.edu), University of Louisiana at Lafayette Thomas Noser, (E-mail: thomas.noser@wku.edu), Western Kentucky University Hal Langford, (E-mail: langford@tamu-commerce.edu), Texas A\&M University, Commerce

\begin{abstract}
This study analyzes the perceptions and preferences of a group of undergraduate business students with respect to taking on-line or distance education courses. In this last decade, distant learning programs have become very popular, and the number of offerings continues to increase. The growing popularity of this medium for instruction is due to a combination of factors. Technological advances have made the availability both economical and practical. The economic advantages of distributing scarce resources, geographically and temporally, to students in remote locations provide a broader market for distance education. Additionally, the increasing demand from students to acquire education at times that are convenient given their busy schedules and personal commitments makes distance education attractive to working learners (Roberts 1998). The new opportunities distance learning has provided have enabled students to create an atmosphere for learning at home.
\end{abstract}

The distance debate usually focuses on issues related to student learning and outcomes and student attitudes as compared to traditional classroom-based settings (Phillips, 1998; Webster \& Hackley, 1997). This study attempts to address these and other topics such as what is distance learning, what are the advantages and disadvantages, and what changes can be made to improve this type of learning. This research is intended to give students a realistic expectation of what to anticipate from distance learning courses based on information we have found and studies we have done. It is important that students have a realistic perception of the distant learning experience.

\section{Introduction}

Distance learning can be defined as instruction not bound by time or place. This type of learning removes the physical and time constraints for the teacher as well as the student. Distance learning can more formally be defined as any course delivered with tools or technologies designed to overcome the restrictions of either same-time or same-place learning. In traditional education, "brick and mortar" limit enrollments. Such limitations cannot be easily corrected in the short run. However, with distance education and the appropriate technology, it is technically possible for an institution located in one local to have most of its students located in remote locations hundreds of miles away (Daniel, 1997; Lewis, Alexander \& Farris 1997).

Readers with comments or questions are encouraged to contact the authors via email. 
For the institution, distance-learning programs can initially be expensive and time consuming. For the instructor, the first crucial step is the choosing of a type of instruction that is designed for the new paradigm of distance learning. This is followed by the transformation of traditional education techniques to the new methodology. Students must also change their focus when in distance education. This analysis focuses on the student. The students not only need traditional printed material, such as textbooks or other reading, but also must have access and a working knowledge of web-based technology including the internet, e-mail, chat rooms and bulletin boards. Distance learning courses offer significant differences from the classic classroom environment. There is no face-to-face contact, no context clues or opportunity for immediate dyadic communication. In the first few weeks of the course, students usually feel high anxiety due to the uncertainty of what the professor really wants and, as a result, the professor is bombarded with e-mails. When both the professor and the student get comfortable with this new environment real learning can take place.

\section{Methodology}

The purpose of this paper is to determine the perceptions of undergraduate business students toward online courses. With the increasing interest in online education, such private institutions as the University of Phoenix have become much more appealing to all persons interested in pursuing a college degree, and according to the University of Phoenix, students can earn degrees whenever and wherever they want, via the Internet ("U. of Phoenix Online' brochure, 2001). Because these institutions have begun to offer more courses online, other universities, both public and private, are showing more interest, also. However, for such a program to proliferate, students' attitudes toward online course offerings should be assessed.

With this in mind, a questionnaire was developed to determine the attitudes of business students at a medium-sized southern university. The instrument was pilot-tested on a sample of 20 students and further improvements were made. The questionnaire was then given to five hundred fifty-eight (558) undergraduate students at two regional state universities, composed of one hundred twenty-six (126) who had taken courses online, and four hundred thirty (432) who had not taken any courses online. In addition to demographic questions on gender, age, gradepoint average, enrollment status, classification, and whether or not the student had ever taken an online course, there were also sixteen (16) Likert-type questions concerning online courses and related statements with which the students could express various levels of agreement or disagreement (1=Strongly Agree; $2=$ Agree; $3=$ Neither Agree nor Disagree; 4=Disagree; 5=Strongly Disagree).

Percent responses to the Likert questions will be presented in total, and for students who have and have not taken courses online, in order to assess attitudes toward online courses. Also, tests of significance will be made to determine if there are significant differences in responses for students who have taken online courses, and for those who have not taken courses online.

The results should be of interest to faculty members, other students, and university administrators who plan to teach, take, or offer online courses in the future. Since many universities are still in the early stages of deciding whether to offer such courses, this information may be helpful in deciding what type of courses at their universities might be offered online, and in structuring these online offerings.

\section{Findings/Results}

Table 1 gives a demographic profile of all respondents, and for students who had and had not taken courses online. As can be seen from the table, the entire group consisted of more females than males, with the majority aged 21 years old or less. The mean grade-point average was 3.049, and almost all the respondents were full-time students, with eighty-eight percent classified as juniors or seniors, and more than ninety-one percent majored in some area of business. With respect to online course experience, nearly twenty-three percent of the respondents had taken an online course prior to this questionnaire. 


\begin{tabular}{|c|c|}
\hline \multicolumn{2}{|c|}{$\begin{array}{l}\text { Table } 1 \text { Demographic Profiles Of All Respondents }(\mathrm{N}=558) \text {, } \\
\text { Respondents Who Had Taken Courses Online }(\mathrm{N}=\mathbf{8 8}) \text {, } \\
\text { And Respondents Who Had Not Taken Courses Online }(\mathrm{N}=157)\end{array}$} \\
\hline Demographic Variables & All Respondents $(n=558)$ \\
\hline $\begin{array}{l}\text { Gender: } \\
\text { Males } \\
\text { Females }\end{array}$ & $\begin{array}{l}44.9 \% \\
55.1 \%\end{array}$ \\
\hline $\begin{array}{l}\text { Age Groups: } \\
21 \text { or less } \\
\text { Over } 21\end{array}$ & $\begin{array}{l}54.7 \\
45.3\end{array}$ \\
\hline Mean Grade-point Average: & 3.049 \\
\hline $\begin{array}{l}\text { Enrollment Status: } \\
\text { Part-time } \\
\text { Full-time }\end{array}$ & $\begin{array}{c}3.9 \% \\
96.1 \%\end{array}$ \\
\hline $\begin{array}{l}\text { Classification: } \\
\text { Freshman } \\
\text { Sophomore } \\
\text { Junior } \\
\text { Senior }\end{array}$ & $\begin{array}{l}0.4 \% \\
11.6 \% \\
41.6 \% \\
46.4 \%\end{array}$ \\
\hline $\begin{array}{l}\text { Major: } \\
\text { College of Business Major } \\
\text { Non-College of Business Major }\end{array}$ & $\begin{array}{c}91.3 \% \\
8.7 \%\end{array}$ \\
\hline $\begin{array}{l}\text { Have You Taken an Online Course Before? } \\
\text { Yes } \\
\text { No }\end{array}$ & $\begin{array}{l}22.7 \% \\
77.3 \%\end{array}$ \\
\hline
\end{tabular}

Table 2 shows the results of significance tests between male and female students to the sixteen Likerttype statements. As the table shows, two significant differences were found. Males were significantly more likely to take a statistics or other quantitative course online (\#8) than were females, even though both groups agreed that math and other quantitative courses were among the most difficult of all their college courses (\#4). Also, males were significantly more likely to take more online courses in the future (\#10) than were females, who actually disagreed with this statement on the average. A possible explanation for these two differences might be male students enjoy the informality associated with online courses more than females; i.e., males prefer to work outside the classroom more than do females, and do not like being required to be officially in attendance at a regularly-scheduled class. This would also be a possible explanation as to why males showed a significantly stronger tendency to take a statistics or other quantitative course online (however, it should be noted here that neither group actually agreed with this statement, but male respondents showed less disagreement than females, and were practically neutral in their average responses). Additionally, it is possible that many females prefer the order associated with the formal classroom setting, as well as the social components that are of course absent with an online course.

With respect to gender differences on the other Likert-type questions, none were revealed. Both groups agreed that online courses have flexible class times (\#1), and that such courses allows students to study at their own pace (\#5). Both male and female respondents also agreed that online classes often require students to teach themselves the material (\#14).

Both genders liked the fact that there was no structured classroom environment (\#9) with online courses, though both genders agreed they would miss the interaction with other students that a traditional class might provide (\#11). Nevertheless, both groups were practically neutral about the importance of meeting and interacting with other students outside of the classroom (\#7). Both groups also showed relatively strong agreement that online courses require students to be self-disciplined (\#16).

Both groups showed the same level of agreement with the statement that there is more interaction with the instructor in a regular classroom course than with an online course (\#3); this would not be agreeing with the obvious, as one might deduce at first glance, because online courses can require a substantial amount of interaction with the instructor as well. Both groups agreed that the textbook is more important with online courses than regular courses (\#12), and that liberal arts classes would work well if offered online (\#2). Both groups were essentially neutral with respect to whether tests with online courses are more difficult, perhaps because of other confounding variables associated with testing in general (such as nature of the material, instructor style, number of hours spent studying for the test, etc.). Lastly, both male and female respondents agreed that technology required to take online courses increases the value of the experience (\#15). 
Table 2: Results Of Comparisons Of Attitudes Of Male Vs. Female Respondents Toward Online Course Offerings And Related Statements

\begin{tabular}{|c|c|c|c|c|c|c|}
\hline \\
\hline \multirow[b]{2}{*}{ Likert Statements } & \multicolumn{2}{|c|}{ Mean Responses* } & \multicolumn{2}{|c|}{ Standard Deviations } & \multirow[b]{2}{*}{ t-stat } & \multirow[b]{2}{*}{ p-value } \\
\hline & Males & Females & Males & Females & & \\
\hline $\begin{array}{l}\text { 1. One of the advantages of taking a } \\
\text { course online is that class times are } \\
\text { flexible. }\end{array}$ & 1.78 & 1.71 & 1.00 & 0.96 & 0.888 & .375 \\
\hline $\begin{array}{l}\text { 2. I believe that a class in liberal arts, } \\
\text { such as history, psychology, soci- } \\
\text { ology, etc., would work well if of- } \\
\text { fered online. }\end{array}$ & 2.49 & 1.14 & 2.43 & 1.20 & 0.568 & .557 \\
\hline $\begin{array}{l}\text { 3. The interaction/lectures with the in- } \\
\text { structor is greater in a regular class- } \\
\text { room setting than in an online } \\
\text { class. }\end{array}$ & 2.20 & 2.04 & 1.18 & 1.06 & 1.773 & .077 \\
\hline $\begin{array}{l}\text { 4. Math and other quantitative courses } \\
\text { are among the most difficult of all } \\
\text { my college courses. }\end{array}$ & 2.69 & 2.53 & 1.38 & 1.39 & 1.328 & .185 \\
\hline $\begin{array}{l}\text { 5. I believe taking a course online al- } \\
\text { lows studying at your own pace. }\end{array}$ & 2.14 & 2.16 & 0.99 & 1.02 & -0.202 & .840 \\
\hline $\begin{array}{l}\text { 6. In my opinion, management } \\
\text { courses should not be offered on- } \\
\text { line. }\end{array}$ & 3.26 & 3.21 & 1.15 & 1.08 & 0.560 & .575 \\
\hline $\begin{array}{l}\text { 7. Meeting with other students outside } \\
\text { of class is important to me. }\end{array}$ & 2.93 & 3.02 & 1.12 & 1.17 & -0.904 & .366 \\
\hline $\begin{array}{l}\text { 8. I would take a statistics or other } \\
\text { quantitative class online if it was } \\
\text { offered. }\end{array}$ & 3.02 & 3.55 & 1.34 & 1.30 & -4.695 & $.000 * *$ \\
\hline $\begin{array}{l}\text { 9. The fact that in an online class } \\
\text { there is no structured classroom- } \\
\text { type environment appeals to me. }\end{array}$ & 2.66 & 2.79 & 1.06 & 1.12 & -1.377 & .169 \\
\hline $\begin{array}{l}\text { 10. In the future, I will take as many } \\
\text { courses as possible online. }\end{array}$ & 2.90 & 3.11 & 1.22 & 1.19 & -2.067 & $.039 * *$ \\
\hline $\begin{array}{l}\text { 11. I would miss the interaction with } \\
\text { other students in an online class. }\end{array}$ & 2.77 & 2.78 & 1.20 & 1.22 & -0.185 & .854 \\
\hline $\begin{array}{l}\text { 12. The textbook is more important in } \\
\text { an online class. }\end{array}$ & 2.32 & 2.19 & 1.12 & 1.02 & 1.449 & .148 \\
\hline $\begin{array}{l}\text { 13. Tests in an online class are more } \\
\text { difficult. }\end{array}$ & 2.98 & 2.91 & 0.76 & 0.73 & 1.125 & .261 \\
\hline $\begin{array}{l}\text { 14. Online classes require the students } \\
\text { to teach themselves the material. }\end{array}$ & 2.22 & 2.15 & 1.01 & 0.94 & 0.783 & .434 \\
\hline $\begin{array}{l}\text { 15. The technology required to take an } \\
\text { online course increases the value of } \\
\text { the experience. }\end{array}$ & 2.55 & 2.55 & 0.98 & 0.91 & 0.000 & 1.000 \\
\hline $\begin{array}{l}\text { 16. Online classes require the student } \\
\text { to be self-disciplined. }\end{array}$ & 1.71 & 1.56 & 0.98 & 0.92 & 1.906 & .057 \\
\hline
\end{tabular}

*1 = Strongly Agree; 2 = Agree; 3 = Neither Agree nor Disagree; 4 = Disagree; 5 = Strongly Disagree

**Significant at .05 or less level 
Table 3: Results Of Comparisons Of Attitudes Of Respondents Aged 21 Or Less Vs. Respondents Older Than 21 Toward Online Course Offerings And Related Statements

\begin{tabular}{|c|c|c|c|c|c|c|}
\hline \multirow[b]{2}{*}{ Likert Statements } & \multicolumn{2}{|c|}{ Mean Responses* } & \multicolumn{2}{|c|}{ Standard Deviations } & \multirow[b]{2}{*}{ t-stat } & \multirow[b]{2}{*}{ p-value } \\
\hline & $\begin{array}{l}21 \text { or } \\
\text { Less }\end{array}$ & $\begin{array}{c}\text { Older } \\
\text { Than } 21 \\
\end{array}$ & $\begin{array}{l}21 \text { or } \\
\text { Less }\end{array}$ & $\begin{array}{c}\text { Older Than } \\
21 \\
\end{array}$ & & \\
\hline $\begin{array}{l}\text { 1. One of the advantages of taking a } \\
\text { course online is that class times are } \\
\text { flexible. }\end{array}$ & 1.79 & 1.65 & 0.91 & 1.01 & 1.622 & .105 \\
\hline $\begin{array}{l}\text { 2. I believe that a class in liberal arts, } \\
\text { such as history, psychology, sociol- } \\
\text { ogy, etc., would work well if offered } \\
\text { online. }\end{array}$ & 2.47 & 2.42 & 1.14 & 1.20 & 0.450 & .653 \\
\hline $\begin{array}{l}\text { 3. The interaction/lectures with the in- } \\
\text { structor is greater in a regular class- } \\
\text { room setting than in an online class. }\end{array}$ & 2.03 & 2.22 & 1.07 & 1.16 & -1.948 & .052 \\
\hline $\begin{array}{l}\text { 4. Math and other quantitative courses } \\
\text { are among the most difficult of all } \\
\text { my college courses. }\end{array}$ & 2.65 & 2.49 & 1.41 & 1.33 & 1.333 & .183 \\
\hline $\begin{array}{l}\text { 5. I believe taking a course online al- } \\
\text { lows studying at your own pace. }\end{array}$ & 2.20 & 2.08 & 0.98 & 1.03 & 1.316 & .189 \\
\hline $\begin{array}{l}\text { 6. In my opinion, management courses } \\
\text { should not be offered online. }\end{array}$ & 3.16 & 3.30 & 1.01 & 1.23 & -1.430 & .153 \\
\hline $\begin{array}{l}\text { 7. Meeting with other students outside } \\
\text { of class is important to me. }\end{array}$ & 2.92 & 3.06 & 1.16 & 1.13 & -1.458 & .145 \\
\hline $\begin{array}{l}\text { 8. I would take a statistics or other } \\
\text { quantitative class online if it was of- } \\
\text { fered. }\end{array}$ & 3.39 & 3.23 & 1.28 & 1.40 & 1.348 & .178 \\
\hline $\begin{array}{l}\text { 9. The fact that in an online class there } \\
\text { is no structured classroom-type envi- } \\
\text { ronment appeals to me. }\end{array}$ & 2.73 & 2.69 & 1.07 & 1.13 & 0.483 & .629 \\
\hline $\begin{array}{l}\text { 10. In the future, I will take as many } \\
\text { courses as possible online. }\end{array}$ & 3.20 & 2.76 & 1.14 & 1.27 & 4.145 & $.000 * *$ \\
\hline $\begin{array}{l}\text { 11. I would miss the interaction with } \\
\text { other students in an online class. }\end{array}$ & 2.77 & 2.79 & 1.24 & 1.18 & -0.177 & .860 \\
\hline $\begin{array}{l}\text { 12. The textbook is more important in an } \\
\text { online class. }\end{array}$ & 2.20 & 2.77 & 1.02 & 1.12 & -0.775 & .439 \\
\hline $\begin{array}{l}\text { 13. Tests in an online class are more dif- } \\
\text { ficult. }\end{array}$ & 2,97 & 2.93 & 0.72 & 0.81 & 0.602 & .548 \\
\hline $\begin{array}{l}\text { 14. Online classes require the students to } \\
\text { teach themselves the material. }\end{array}$ & 2.16 & 2.20 & 0.90 & 1.06 & -0.494 & .621 \\
\hline $\begin{array}{l}\text { 15. The technology required to take an } \\
\text { online course increases the value of } \\
\text { the experience. }\end{array}$ & 2.61 & 2.50 & 0.87 & 1.04 & 1.365 & .173 \\
\hline $\begin{array}{l}\text { 16. Online classes require the student to } \\
\text { be self-disciplined. }\end{array}$ & 1.64 & 1.57 & 0.96 & 0.92 & 0.843 & .400 \\
\hline
\end{tabular}

$* 1$ = Strongly Agree; 2 = Agree; 3 = Neither Agree nor Disagree; 4 = Disagree; 5 = Strongly Disagree

**Significant at .05 or less level 
In Table 3, tests of significance between respondents aged twenty-one years old or less and respondents older than twenty one are shown (age twenty-one was the median age of these respondents). As can be seen from the table, only one significant difference resulted. Students over the age of twenty-one were more likely to take an online course or courses in the future than were students ages twenty-one or less. This stands to reason, since older students can take these courses at home and not have to worry about attending a formal class, thereby allowing them to pursue their careers and/or spend time with their families. Also, the older group should be more mature and possibly more self-motivated than those aged twenty-one or less.

There were no other significant differences between the older and younger respondents. The mean responses basically mirrored those of Table 2 .

Table 4 shows the results of significance tests between respondents with previous online course experiences and those without such experiences, the area where one might reasonably expect significant differences to exist. Even though there were more respondents who had not taken an online course before, there were enough in each group to make the results meaningful. As can be seen from the table, students who had taken at least one online course showed significantly more agreement with the statement that online courses offer more flexibility with respect to class times (\#1) and that online courses permit students to study at their own pace (\#5). The online respondents felt significantly stronger about the appeal of the non-structured classroom environment associated with online courses (\#9). They also showed stronger agreement with the statement that online classes require more selfdiscipline (\#16), though both groups showed about the same level of agreement with the statement that online classes basically require students to teach themselves (\#14).

Both groups agreed that liberal arts courses would work well if offered online (\#2), but the respondents with previous online experience showed a stronger level of disagreement with the statement that management courses should not be offered online (\#6). Similarly, both groups exhibited about the same level of agreement that math and quantitative courses were among the most difficult in college for them (\#4), and both groups disagreed that they would take a statistics or other quantitative course online if such a course was offered (\#8).

While both groups understood that instructor-student interactions are greater in regular classes, the respondents with no previous online experience showed a stronger level of agreement with this statement (\#3). Not surprisingly, this group is less inclined to take online courses in the future (\#10). This same non-online group also felt that they would miss the interaction with other students in an online class than did the respondents with online experience (\#11), who actually disagreed with this statement. Both groups were relatively neutral on the issue of the importance of meeting with other students outside the classroom.

When asked about their perceptions of the importance of the textbook in an online class, both groups had about the same level of agreement with the statement that the textbook is more important in such classes (\#12). But when asked about testing in online versus non-online classes, the non-online respondents showed significantly more agreement with the statement that tests were more difficult in such classes than did the online students, who actually showed a slight level of disagreement (\#13).

With respect to technology, while both groups agreed that the technology required to take online classes increases the value of the experience, the online group showed a significantly stronger level of agreement with this statement than did the non-online students (\#15). As one might expect, the students who had already taken course(s) online were significantly more likely to take more online courses in the future than were those without any online courses (in fact, this group showed a slight level of disagreement with this statement (\#10).

\section{Summary And Conclusions}

The results of this research shows that with respect to perceptions of online courses, regardless of age or gender, respondents feel basically the same, with only a small number of differences. However, when the respondents were divided by their previous online experience, numerous differences were found. These differences range from the advantages of taking online courses, to the difficulties of tests and the types of courses to be offered. Gen- 
erally speaking, students who had taken at least one online course had a more favorable impression of such courses, and said they would like to take more courses in the future. This would suggest that before offering online courses, professors and/or administrators might wish to more effectively communicate some of the benefits of these courses in order to reduce the resistance to them. Perhaps a detailed description of the course and what it entails should be made available to prospective students well in advance of the time that the course will be offered. Also, if possible, teachers could use former students to serve as "walking, talking advertisements" of the virtues of such courses. At any rate, while the success of online courses might not depend totally on communicating what such courses involve, certainly some of the resistance to them could be alleviated by setting up a long-range plan which would focus on making more knowledge about these courses available to future students.

Table 4: Results Of Comparisons Of Attitudes Of Online Vs. Non-Online Respondents Toward Online Course Offerings And Related Statements

\begin{tabular}{|c|c|c|c|c|c|c|}
\hline \multirow[b]{2}{*}{ Likert Statements } & \multicolumn{2}{|c|}{ Mean Responses* } & \multicolumn{2}{|c|}{ Standard Deviations } & \multirow[b]{2}{*}{ t-stat } & \multirow[b]{2}{*}{ p-value } \\
\hline & Online & Non-online & Online & Non-online & & \\
\hline $\begin{array}{l}\text { 1. One of the advantages of taking a } \\
\text { course online is that class times are } \\
\text { flexible. }\end{array}$ & 1.23 & 1.90 & 0.71 & 0.99 & 7.006 & $.000 * *$ \\
\hline $\begin{array}{l}\text { 2. I believe that a class in liberal arts, } \\
\text { such as history, psychology, sociol- } \\
\text { ogy, etc., would work well if offered } \\
\text { online. }\end{array}$ & 2.37 & 2.48 & 1.22 & 1.16 & 1.000 & .318 \\
\hline $\begin{array}{l}\text { 3. The interaction/lectures with the in- } \\
\text { structor is greater in a regular class- } \\
\text { room setting than in an online class. }\end{array}$ & 2.37 & 2.04 & 0.99 & 1.14 & 2.931 & $.004 * *$ \\
\hline $\begin{array}{l}\text { 4. Math and other quantitative courses } \\
\text { are among the most difficult of all } \\
\text { my college courses. }\end{array}$ & 2.52 & 2.63 & 1.44 & 1.37 & 0.801 & .423 \\
\hline $\begin{array}{l}\text { 5. I believe taking a course online al- } \\
\text { lows studying at your own pace. }\end{array}$ & 1.79 & 2.25 & 1.05 & 0.98 & 4.582 & $.000 * *$ \\
\hline $\begin{array}{l}\text { 6. In my opinion, management courses } \\
\text { should not be offered online. }\end{array}$ & 3.48 & 3.16 & 1.18 & 1.08 & 2.925 & $.004 * *$ \\
\hline $\begin{array}{l}\text { 7. Meeting with other students outside } \\
\text { of class is important to me. }\end{array}$ & 3.13 & 2.93 & 1.04 & 1.18 & 1.696 & .091 \\
\hline $\begin{array}{l}\text { 8. I would take a statistics or other } \\
\text { quantitative class online if it was of- } \\
\text { fered. }\end{array}$ & 3.11 & 3.37 & 1.43 & 1.31 & 1.899 & .058 \\
\hline $\begin{array}{l}\text { 9. The fact that in an online class there } \\
\text { is no structured classroom-type envi- } \\
\text { ronment appeals to me. }\end{array}$ & 2.34 & 2.84 & 1.14 & 1.06 & 4.536 & $.000 * *$ \\
\hline $\begin{array}{l}\text { 10. In the future, I will take as many } \\
\text { courses as possible online. }\end{array}$ & 2.33 & 3.22 & 1.19 & 1.14 & 7.558 & $.000 * *$ \\
\hline $\begin{array}{l}\text { 11. I would miss the interaction with } \\
\text { other students in an online class. }\end{array}$ & 3.24 & 2.64 & 1.20 & 1.18 & 4.968 & $.000 * *$ \\
\hline $\begin{array}{l}\text { 12. The textbook is more important in an } \\
\text { online class. }\end{array}$ & 2.15 & 2.28 & 1.16 & 1.04 & 1.163 & .245 \\
\hline $\begin{array}{l}\text { 13. Tests in an online class are more dif- } \\
\text { ficult. }\end{array}$ & 3.09 & 2.90 & 1.03 & 0.64 & 2.458 & $.014 * *$ \\
\hline $\begin{array}{l}\text { 14. Online classes require the students to } \\
\text { teach themselves the material. }\end{array}$ & 2.08 & 2.21 & 1.08 & 0.94 & 1.363 & .173 \\
\hline $\begin{array}{l}\text { 15. The technology required to take an } \\
\text { online course increases the value of } \\
\text { the experience. }\end{array}$ & 2.12 & 2.68 & 0.97 & 0.90 & 6.071 & $.000 * *$ \\
\hline $\begin{array}{l}\text { 16. Online classes require the student to } \\
\text { be self-disciplined. }\end{array}$ & 1.35 & 1.71 & 0.67 & 1.00 & 3.795 & $.000 * *$ \\
\hline
\end{tabular}

*1 = Strongly Agree; 2 = Agree; 3 = Neither Agree nor Disagree; 4 = Disagree; 5 = Strongly Disagree

$* *$ Significant at .05 or less level 


\section{References}

1. Daniel, J. (1997). "Why universities need technology strategies". Change, 29, 10-17.

2. Lewis, L., Alexander, D., \& Farris E. (1997). "Distance education in higher education institutions" (NCES 98-062): Washington, D.C.: U.S. Department of Education Office of Educational Technology National Center for Education Statistics.

3. Phillips, F. (1998). "On line University teach knowledge beyond the books". HR Magazine, 43(8), 120-128.

4. $\quad$ Roberts, B. (1998). "Training via desktop". HR Magazine, 43(9), 98-104.

5. University of Phoenix Online brochure, University of Phoenix, 2000.

6. Webster, J., \& Hacklery, P. (1997). "Teaching effectiveness in technology mediated distance learning". Academy of Management Journal, 40 (6), 1282-1309.

Notes 